\title{
RED PALM WEEVIL - A SERIOUS PEST OF COCONUT AND ITS BIOLOGICAL CONTROL MEASURES
}

\author{
Logeshwar Balakrishnan \\ RVS Padmavathy College of Horticulture, Tamilnadu, India. \\ DOI: 10.46609/IJAER.2020.v06i03.006 URL: https://doi.org/10.46609/IJAER.2020.v06i03.006
}

\begin{abstract}
Red palm weevil Rhychophorus ferrugineus (Olivier) Curculionidae: Coleoptera, a tissue boring insect is a serious pest in most of the palms. In India, it is a dangerous pest of coconut. Both larva and adult are the pests of the crop. The adult injures the palm with its snout for oviposition or lays eggs on the wounds found in the palms and the larva feeds on the soft tissues of the palm. The main symptoms of the attack of red palm weevil are oozing out of thick brown to yellowish fluids from the tunnels, appearance of the frass around the opening of the tunnels. Newer infestations are hardly detected and early detection of the infestations is also difficult. Thus it becomes a menace for the control of this pest. Avoiding wounds on the palms and clean cultivation of the crop can avoid the infestation to a considerable extent. The use of pesticides can control the infestation at the initial stages. But the use of chemical pesticides is found to deteriorate the quality of the crop as well as the land. Chemical pesticides are non-ecofriendly and non-human friendly. So this article suggests on the various available biological control of the pest such as pheromone traps, entomopathogenic organisms, predators and parasitoids. Biotechnological methods such as suppression of the vitellogenin genes and shredding of the $\mathrm{x}$ chromosomes can control the pest to a greater extent.
\end{abstract}

Keywords: red palm weevil, chemical pesticides, environmental problems, biological control, vitellogenin gene suppression, $\mathrm{X}$-chromosome shredding

\section{INTRODUCTION}

The red palm weevil is indigenous to South Asia. The spread and occurrence of this pest increased only during the last three decades. The spread is mainly due to the transport of the infested planting materials and the movement of infested palms [3]. This pest widely attacks about 26 species of palms belonging to 16 genera across the globe. This pest was first reported in coconut (cocos nucifera) in Southeast Asia [7]. Several quarantine rules are imposed in many 
International Journal of Agriculture and Environmental Research

ISSN: $2455-6939$

Volume: 06, Issue: 03 "May-June 2020"

countries to prevent the spread of this pest. It is estimated that about $10 \%$ of the palms in India are destroyed annually due to its attack.

\section{BIOLOGY}

The redpalm weevil easily attacks the previously infested palm. The lifecycle of the pest is of 4 stages - egg, larva, pupa, and adult. Most of its life stages are found inside the palm. The adult after copulation makes use of the wound present in the palm for oviposition, likely the soft tissue after the pruning of the dried fronds. In some cases, the adult injures the crown of the palm with its snout for oviposition [9] and checks whether the site is suitable for laying eggs. A female weevil can lay up to 530 eggs when fertilized [14]. The eggs are pale yellow, oval and cylindrical. The eggs start to hatch from 4 to 6 days.

The hatched larva is white to pale yellow with a reddish cap in the head region. The larval instars of the pest vary depending upon the host and climatic conditions. The larva is apodous [12]. The larva starts to feed on the soft tissues of the heart of the palm and tunnels down [13]. The larval stages are only seen inside the palm they never come out. Due to the feeding of the larva, a brownish liquid oozes out of the tunnels of the trunk. This stage of grub varies from 25 to 105 days [12]. After this, the grub enters into the pre-pupal stage [13]. This stage lasts for 3 days.

The pupal stage of the insects lasts for 11-45 days. The pupa is covered by a cocoon made up of the chewed out fibrous frass material [14]. The pupal stage is found inside the tunnels made by the grubs.

\section{DAMAGE BY PEST}

Both adults and the grub causes damage to the palm. The grub bores into the soft tissues of the heart of the palm [4] and makes tunnels. With the infestation of the pest, ooze out of light yellow to brown colored liquid like resin is found from the mouth of the tunnels [1] and it gives out a fermented odor. The fibrous chewed out materials are also pushed out of the tunnels. Due to the exposure of these tissues, it further leads to secondary infections such as fungi thus killing the crop [9]. Mostly the early stages of infestations are hard to detect [7] thus making this pest a menace and hard to control. Sometimes the pupal cases are found at the base of the palm. In severe stages of infestation, the crown of the palm is mottled and malformed eventually leading to the baldness of the palm [5].

\section{MANAGEMENT}

The infestation of red palm weevil is detected from the above-studied symptoms. Detection at that time is too late for its control so early detection of the pest occurrence is necessary. The grubs produce a gnawing sound which is amplified by certain instruments [7] and easily detected 
International Journal of Agriculture and Environmental Research

ISSN: 2455-6939

Volume: 06, Issue: 03 "May-June 2020"

earlier. The other methods of early detection are thermal imaging and using ultrasonic instruments [9]. These instruments are costlier and cannot be afforded by all the farmers.

\section{CHEMICAL CONTROL}

Application of $1 \%$ carbaryl $50 \mathrm{WP}$ and $0.1 \%$ endosulfan 35EC can control the pest [4]. These chemicals are either provided by root feeding or by stem injection [4] which controls the grub. The use of celphos tablets (aluminum phosphide) [6] can control the pest. Root feeding and trunk injection of monocrotophos [7] are also known to control the pest. Harvesting immediately after the application of pesticides needs to be avoided as the edible part of the crop might have the chemical residue. Moreover, this method is not human-friendly and environment friendly. So other better methods of control of this pest must be used.

\section{CULTURAL CONTROL}

Field sanitation can control the occurrence of the pest to a greater extent. Treat the injured part of the palm after pruning the fronds with insecticides [6] or with coal tars which prevent the oviposition of the adult insects. When the palms are found to be fully damaged and cannot be recovered remove the palm from the field and shred it thus destroying the pest in the palm. The use of ferrugineol as a lure in the pheromone trap was found to attract more amount of female insects than male insects [5]. The ratio of female insects to the male insect that gets trapped is $2: 1$. The use of food bait containing palm tissues, sugarcane in a liter of water along with the pheromone trap was found to be more effective [6] [12]. The use of the Pheromone trap in shade at a rate of 1 per hectare [12] is recommended.

\section{BIOLOGICAL CONTROL}

Several microscopic organisms that are entomopathogenic are known to control this pest. A high potent cytoplasmic polyhedrosis virus is known to infect all stages of the insect [8]. The adult from the infected larva is known to be malformed in laboratory researches. In the case of bacterial pathogens, when the pest is inoculated with Pseudomonas aeruginosa the pest dies after the eighth day of inoculation [8] but this bacterium cannot be used as it is known to infect the respiratory tract of humans also. Another kind of bacteria, Bacillus licheniformis is known to have ovicidal and larvicidal characteristics on the pest [9]. Strains of Beauveria bassiana, an entomopathogenic fungus [2] is known to control the pest. The spores of this fungus, when inoculated with the pest, start to grow on the cuticle of the pest and cover the entire body thus killing the insect. The fungi also can transmit from a previously infected cadaver. The suitable formulations of the above-mentioned virus, bacteria, and fungi can be sprayed or applied in any means which can control the pest. 
International Journal of Agriculture and Environmental Research

ISSN: $2455-6939$

Volume: 06, Issue: 03 "May-June 2020"

The bacterial genera Xenorhabdus and Photorhabdus are naturally housed in the entomopathogenic nematodes such as steinernema carpocapse and Heterorhabditis bacteriophora [10] [6]. Both the organisms are symbiotic in relationship. The toxins produced by these bacteria provide feed to the nematodes while they are detrimental to red palm weevil. The nematodes enter the pest through all the natural openings and also through the cuticle and release the bacteria in the haemocoel [6]. The nematodes are found as clusters in the ovipositor also. These nematodes are released along with the feces and during oviposition thus carrying out the infection chain. These nematodes don't infect the palms and the untargeted vertebrates. Nematodes kill the insect within 48 hours of infestation [10]. They are considered to be faster than the above mentioned other entomopathogenic microorganisms. These nematodes can be cultured easily and cost-effectively. The suitable formulations of these nematodes are sprayed on the infected palm thus infecting the red palm weevil.

Certain insects are also used in the control of red palm weevil and they are called entomophagous insects that are capable of feeding on specific life stages of the pest. Predatory coleopterans such as rove beetle (xanthopygus cognatus) feed on the egg and larvae of red palm weevil [1]. It is a facultative monophagous insect that is capable of feeding on the other pest of the palm when red palm weevil is not available [1]. Many species of mites and earwigs are found as natural enemies of red palm weevil. But their action is uncertain. Further research is required for use of these insects as predators of redpalm weevil. Certain insects of the order Diptera are used as parasitoids. Sarcophaga fuscicauda Bottcher belonging to the order Diptera attacks the adults of red palm weevil [8]. The larvae of the fly feed on the larva and the adult of the pest. Flies of the species paratheresia belonging to the Tachinidae family are internal parasitoids [8] especially of the members of the order Lepidoptera and Coleoptera. So this insect can be used as a control material for other pests of coconut palm such as white grubs, black-headed caterpillar. But further studies are needed to use these tachinids as a biocontrol material.

\section{MOLECULAR APPROACH}

Early detection of the pest occurrence is necessary for the control of the pest. Though there are certain measures for early detection they are not affordable by all the farming communities. So neglecting the reproducing ability of the pest can control its population and avoid infestation. The two necessary genes for the reproduction of the pest are vitellogenin gene ( $\mathrm{Vg}$ ), its receptor $(\mathrm{VgR})$ and odorant receptor gene (OR) [11]. Vitellogenin gene is a major yolk protein precursor critical for oogenesis. Suppressing the odorant receptor gene will reduce the olfactory functions, thus making the released pheromones by the opposite sex of no use. RNA interference technology is used in the suppression of $\mathrm{Vg}$. This method showed maximum success in 15 days of the post-injection period [11]. This method led to the failure of oogenesis ultimately no hatching of eggs. 
International Journal of Agriculture and Environmental Research

ISSN: $2455-6939$

Volume: 06, Issue: 03 "May-June 2020"

\section{FUTURE PROSPECTS}

It is almost impossible to treat manually every individual of the population of the pest with RNAi technology. So the RNAi is reverse transcribed into DNA and ligated with the plasmids of the bacterium that is capable of infecting the pest (rDNA technology). The specific DNA is materialized in the way that, it is transcribed into RNAi (normally it happens) and gets expressed to complete its target activity. The bacterium is further manipulated to get transmitted from the female pest to the male pest during copulation. So that this technology is transferred from the infected male pest to any other female pest during further copulation and expressed in it. Thus automatically all the individuals of the population would be biologically manipulated by RNAi technology. Further researches are required to make this technique available practically.

Another method to control the population of the weevil is by X-chromosome shredding. In this method, the $\mathrm{X}$-chromosomes are shredded from the set of $\mathrm{X}, \mathrm{Y}$ chromosome from the male, making only Y-chromosome available during mating and subsequently leading to the production of male progenies. This method is developed in the way that the mechanism of X-chromosome shredding is also transferred to the progenies thus subsequently making an imbalance in the pest population having only males and a reduced number of females. In such a way the pest population is controlled. This method is being followed in the mosquitoes that cause malaria. To employ this mechanism in red palm weevil further studies are required.

\section{DISCUSSION}

This article speaks on avoiding the use of chemical control techniques of red palm weevil and enhancing other better techniques. The use of cultural methods such as pheromone trapping and baiting was found useful in the control of pest to a considerable extent. Biological control such as entomopathogenic organisms, predators and parasitoids should be used for better results. Further research and development in the field of molecular biology such as vitellogenin gene suppression and X-chromosome shredding is needed. Development and field application of this technique may completely eradicate the pest, thus serving the farming community.

\section{CONCLUSION}

Among other pests of coconut, red palm weevil is being a serious pest of the palm. Early detection of the pest occurrence is difficult which makes it dangerous. The palm can be saved to a greater extent by chemical pesticides if the pest occurrence is detected early. But the modern early detecting techniques cannot be afforded by all the farmers. The use of chemicals are also known to deteriorate the environment. So farmers themselves are moving towards the cultural control and biological control techniques. Further awareness campaigns and trainings have to be 
International Journal of Agriculture and Environmental Research

ISSN: $2455-6939$

Volume: 06, Issue: 03 "May-June 2020"

provided to the farmers regarding the use of these techniques. In addition development of the molecular techniques is a prime requirement to eradicate the pest to a greater extent.

\section{REFERENCES}

1. Sarwar, M. 2016. Biological Control of Red Palm Weevil Rhynchophorus ferrugineus (Coleoptera: Curculionidae) By the Natural Enemies. International Journal For Research In Biology \& Pharmacy (ISSN: 2208-2093). 2, 7 (Jul. 2016), 22-35.

2. El-Sufty, R., Al-Awash, S.A., Al Amiri, A.M., Shahdad, A.S., Al Bathra, A.H. and Musa, S.A. (2007). BIOLOGICAL CONTROL OF RED PALM WEEVIL, RHYNCHOPHORUS FERRUGINEUS (COL.: CURCULIONIDAE) BY THE ENTOMOPATHOGENIC FUNGUS BEAUVERIA BASSIANA IN UNITED ARAB EMIRATES. Acta Hortic. 736, 399-404 DOI: 10.17660/ActaHortic.2007.736.36

3. Faleiro, J. (2006). A review of the issues and management of the red palm weevil Rhynchophorus ferrugineus (Coleoptera: Rhynchophoridae) in coconut and date palm during the last one hundred years. International Journal of Tropical Insect Science, 26(3), 135-154. doi:10.1079/IJT2006113

4. Al-Dosary, N., S. Al-Dobai, and J. Faleiro. "REVIEW ON THE MANAGEMENT OF RED PALM WEEVIL RHYNCHOPHORUS FERRUGINEUS OLIVIER IN DATE PALM PHOENIX DACTYLIFERA L”. Emirates Journal of Food and Agriculture, Vol. 28, no. 1, Dec. 2015, pp. 34-44, doi:https://doi.org/10.9755/ejfa.2015-10-897. Accessed 11 May 2020.

5. Abraham, V.A., shuaibi, M.A., Faleiro, J.R., Abozuhairah, R.A., Vidyasagar, P.S., 1998. An integrated management approach for red palm weevil Rhynchophorus ferrugineus Oliv. a key pest of date palm in the Middle East. J. Agric. Mar. Sci. [JAMS] 3 (1), 77-83.

6. Murphy, Sean \& Briscoe, B. (1999). The red palm weevil as an alien invasive: biology and the prospects for biological control as a component of IPM A Threat to Palms. Biocontrol News Inf. 20.

7. Kumara, Nishantha thisssa \& Muniyappa, Chandrashekharaiah \& Kandakoor, Subhash \& Chakravarthy, Akshay. (2015). Status and Management of Three Major Insect Pests of Coconut in the Tropics and Subtropics. 10.1007/978-81-322-2089-3_32.

8. Mazza, Giuseppe fl., Valeria Francardi, Sauro Simoni, Claudia Benvenuti, Rita Cervo, Jose Romeno Faleiro Faleiro, Elena Llácer, Santi Longo, Roberto Nannelli, Eustachio Tarasco and Pio Federico Roversi. "An overview on the natural enemies of Rhynchophorus palm weevils, with focus on R. ferrugineus.” (2014).

9. Dembilio, Óscar \& Jacas, J.. (2015). Biology and Management of Red Palm Weevil. 10.1007/978-3-319-24397-9_2. 
ISSN: 2455-6939

Volume: 06, Issue: 03 "May-June 2020"

10. Gozel, Ugur \& Gozel, Cigdem \& Yurt, Çiğdem \& Inci, Deniz. (2015). Efficacy of Entomopathogenic Nematodes on The Red Palm Weevil Rhynchophorus ferrugineus (Olivier, 1790) (Coleoptera: Curculionidae) Larvae. $4 . \quad 4436-4439$. 10.21746/ijbio.2015.10.0020.

11. Aldawood, Abdulrahman. (2016). Integrated research programs for date palm pest management: New initiatives and future perspectives. 1744. 020001. 10.1063/1.4953475.

12. Giblin-Davis, Robin \& Faleiro, J.R. \& Jacas, J. \& Pena, Jorge \& Vidyasagar, Polana. (2013). Biology and Management of the Red Palm Weevil, Rhynchophorus ferrugineus. 10.13140/2.1.1029.1202.

13. El-Mergawy, Rabab \& Ajlan, Aziz. (2011). Red Palm Weevil, Rhynchophorus ferrugineus (Olivier): Economic Importance, Biology, Biogeography, and Integrated Pest Management. Journal of Agricultural Science and Technology A1(1): 1-23.. 1.

14. Anisul Islam Mahmud, Joao Farminhao and Eleonore R.A. Viez, 2015. Red Palm Weevil (Rhynchophorus ferrugineus Olivier, 1790): Threat of Palms. Journal of Biological Sciences, 15: 56-67. 